\title{
Factors Influencing Retail Investor's Trading Behavior in Indian Equity Market
}

\author{
Sashikala P. ${ }^{1} \&$ Girish G. P. ${ }^{2}$ \\ ${ }^{1}$ Department of Operations, IBS Hyderabad, IFHE University,Telangana State, India \\ ${ }^{2}$ Department of Finance, IBS Hyderabad, IFHE University, Telangana State, India \\ Correspondence: Girish G. P., Department of Finance, IBS Hyderabad, IFHE University, Telangana State, India. \\ E-mail: gpgirish.ibs@gmail.com
}

Received: July 15, 2015

doi:10.5539/ijbm.v10n11p206
Accepted: August 25, 2015

Online Published: October 28, 2015

URL: http://dx.doi.org/10.5539/ijbm.v10n11p206

\begin{abstract}
In this study we identify the factors which influence and affect retail investor's trading behavior in Indian equity market. To identify the factors, we use primary data collected from retail investors belonging to different age group, professional backgrounds and demographics of India. The results of the study suggest that factors like broker's advice, personal analysis, current price of the equity stock, financial analyst's recommendations, inclination towards online trading; investor's confidence in advice given by his/her financial advisor plays a major role in influencing and affecting trading behavior of retail investors. The result of the study gives insights to firms offering financial services in developing nation like India to keep these factors in mind while offering products/services or in their marketing campaigns while targeting retail investors of Indian equity market.
\end{abstract}

Keywords: retail investors, equity market, trading behavior, investment, behavioral finance

\section{Introduction}

Capital markets world-wide have significantly facilitated in conversion of savings and disposable income of people into investments both in developed as well as developing nations. The initial public offer or the fresh issue of securities takes place in primary market and trading of the issued securities among investors takes place in secondary market. In India, it has been observed that retail individual investor's participation in the primary market for equity has been massive in the last few decades and is testified by the number of companies that have been offering equity through primary markets (Girish \& Rastogi, 2013). Reforms in Indian financial market such as Screen based trading, Dematerialization of shares, Setting up clearing houses, Proper guidelines and norms for settlement procedures, corporate governance standards has nearly eliminated various risks involved in trading and has motivated Foreign Institutional Investors (FIIs), Individual Retail Investors, Domestic Institutional investors to take cognizance of the highest standard of practices followed in Indian financial market and has been promoting active trading in these markets. Testimony to this fact being the ever increasing number of listed companies, number of participants, market capitalization, products offered, market turnover, liquidity, risk hedging tools available in derivative markets to name a few.

Academic research in finance is based on the assumption that investors are rational which may or may not be the case. Rationality means investors being objective and exhaustive simultaneously for any given input. Considering the fact that human beings are irrational (Von Neumann \& Morgenstern, 1944) leads us to question the underlying assumption of academic research in finance and of-course the findings. There is a need to be acquainted with impact and effect of individual psychological behavior, attitudes and biases of the investors which may lead to different decision making.

The present study is a small attempt in the direction of understanding individual retail investor's trading behavior and contributing in the field of behavioral finance. There is a general notion of apprehension while investing in capital markets especially after the recent Stock market crash in China in 2015 (Keshav \& Girish, 2015), Global Financial crisis in 2008 and the on going crisis in European zone particularly in Greece among Individual Retail Investors. In such a context, the present study is intended to address what are the factors which the firms offering financial services in developing nation like India need to keep in mind while offering products/services and/or in their marketing campaigns while targeting retail investors of Indian equity market. The study intends to embrace 
the issues related to retail investor's behavior and attitude in Indian equity market's context and establish a crucial link between investor's trading behavior and what financial service firms can do from a marketing perspective.

Many studies in literature have focused on psychological biases of individual investors who are trading in equity market without actually identifying the factors which influence Individual retail investor's trading behavior. This is one of those few studies in literature focusing on retail individual investors from a developing nation like India. The rest of the paper is structured as follows: In section 2 we review the literature. In section 3 we describe the data, methodology adopted and explain our findings in Section 4. We conclude our study in Section 5 focusing on implication, limitations and scope for future research in this area.

\section{Literature Review}

Finance as a discipline has evolved over the years and can be classified under three schools of thought: (Haugen, 1999; Ramiah et al., 2015) a) Old finance (where the major focus was on focused on analysis of financial statements including nature of financial claims made). b) Modern finance (where the major focus is on asset pricing and valuations on the basis of rational economic behavior of the participants). c) New Finance (which deals with in-efficient markets by incorporating behavioral models). Proponents of behavioral finance challenge the status quo of finance researchers who tacitly assume rationality of Investor's behavior by making assumptions namely a) Presence of Investor Sentiment b) Speculation against sentimental investors is impossible extremely risky and may prove to be expensive (De Long et al., 1990; Shleifer \& Vishny, 1997). According to modern behavioral finance, Arbitrage has its own limits (Baker \& Wurgler, 2007).

Global evidence suggests investor confidence plays an important role in the well being of a financial market. Though research relating to importance of investor behavior in the Indian capital markets is at a nascent stage, it can't be discounted that behavioral patterns of the investor plays a crucial role. An article in the Economist (1998) indicated that Transparency, strengthening financial system and managing crises are the issues which financial markets face and cannot be quickly fixed. Odean (1998) in his study empirically proves that high volume of trading is related to investors' over-confidence. Loong (2000) highlight the importance of rebuilding investor confidence for prosperity of ASEAN countries post crisis and turbulent macroeconomic environment. Oliver (2002) highlight that more than half of all Canadians have investments in equities and their confidence is essential to healthy and dynamic capital market.

Factors such as deep bear market, corporate scandals; insider trading scandals, high levels of executive compensation and inaccuracy of published financial statements are some of the factors due to which stock market investments are affected especially on the Psyche of small retail investors. McCall (2002) point out that integrity of financial markets and economic well being of the country depend on corporate accountability and investor confidence. Stiglitz and Weiss (1981) have indicated that any bunch of new entrants into the market realm brings with him a can full of frauds and individual retail investors know this, but they cannot identify the frauds.

Islamoğlu et al. (2015) in their study investigated the factors which influenced individual investor's behavior by using data from bankers of Bartın and found that Income, Awareness, Information update, religion and society, banking and payment and investments in other asset classes played a major role in influencing individual investor's behavior. Ramiah et al. (2015) in their study reviewed literature on behavior of noise traders and analyzed the consequences of their existence in the market and identified how noise trading could be related to certain market fundamentals. In our study we investigate the factors which influence and affect retail investor's trading behavior in Indian equity market.

\section{Data and Methodology}

The main objective of the study is to investigate the factors which influence and affect retail investor's trading behavior in Indian equity market by using primary data collected from retail investors belonging to different age group, professional backgrounds and demographics of India. To get primary data we performed a survey using a questionnaire as the medium to extract relevant responses. The responses were collected from those retail individual investors who were willing to spend their time and wished to contribute to research willingly only implying a convenience sample comprising of people pursuing various occupations and belonging to different age group. A five point likert scale was used in the survey (Aziz, 2011). The geographic boundary of the study was limited to Hyderabad city in India.

The initial part of the questionnaire focused on investigating the factors which influence and affect retail investor's trading behavior in Indian equity market and we analyzed the data using Factor Analysis and the 
second part consisted of trying to identify measures which investors perceive would advance investor's confidence in Indian capital markets (Islamoglu et al., 2015). The survey was conducted in December 2014. The participation rate was close to $79.23 \%$. Out of 260 survey questionnaires, we were successful in getting valid responses from 206 retail investors and the results were analyzed using SPSS.

\section{Empirical Findings}

Demographical details of the respondents are elucidated in Table 1. Majority of the respondents were married $(64.56 \%)$ and male respondents accounted for $57.28 \%$ of the total responses. Bulk of the respondents belonged to less than 30 years of age group highlighting the relevance of our study as more than half of Indian population is less than 30 years of age currently. Majority of the respondents were under graduates $(60.19 \%)$ and most of the respondents had an average work experience of less than 5 years.

Table 1. Demographical details of the respondents

\begin{tabular}{lcc}
\hline \multicolumn{3}{l}{ Marital status of the Respondents } \\
Married & 133 & 64.56 \\
Single & 73 & 35.44 \\
Total & 206 & 100 \\
\hline Sex of the Respondents & & \\
Male & 118 & 57.28 \\
Female & 88 & 42.72 \\
Total & 206 & 100 \\
\hline Age group of the Respondents & \\
$21-25$ & 81 & 39.32 \\
26-30 & 92 & 44.66 \\
$31-35$ & 30 & 14.56 \\
36 and Above & 3 & 1.45 \\
Total & 206 & 100 \\
\hline Educational background of the Respondents \\
High school & 12 & 5.82 \\
Under graduation & 124 & 60.19 \\
Post graduation & 67 & 32.52 \\
Ph.D. & 3 & 1.45 \\
Total & 206 & 100 \\
\hline Work experience of the Respondents & \\
2 years and below & 112 & 54.36 \\
3-5 years & 75 & 36.40 \\
5 years and above & 19 & 9.22 \\
Total & 206 & 100 \\
\hline
\end{tabular}

Factor Analysis as defined by Büyüköztürk (2002) is nothing but "multivariate statistical method aiming at discovering and finding abstractly significant variables/factors/dimensions by congregation of associated variables collectively". Factor Analysis aims at facet diminution and dependence exclusion by obtaining few factors out of many factors (Polat, 2012). Factor Analysis could be of two types namely explanatory factor analysis or confirmatory factor analysis. Application of exploratory factor analysis makes sense when researcher is unaware of the relationships between variables considered for the study (Altunışık et al., 2005).

In our study Principal components were analyzed and vari-max rotation was applied in the exploratory factor analysis in order to identify the relevant factors. In each rotation irrelevant items were excluded and the rotation procedure was repeated. It is believed in literature that ideal sample size should be five times number of questions asked, a minimum of 50 observations and more should be considered, validity of application of factor analysis should be investigated using Bartlett's test of sphericity, Kaiser-Meyer-Olkin (KMO) should be checked for sampling adequacy (İslamoğlu, 2011; İslamoğlu et al., 2015).

The Kaiser-Meyer-Olkin (KMO) statistic evaluates sampling adequacy signifying the proportion of variance of the considered variables possibly caused by the underlying factors. KMO statistic value close to 1 indicates that factor analysis possibly will be useful for the considered data and KMO statistic value less than 0.5 indicates that 
factor analysis probably may not be useful. Bartlett's test of sphericity tests the hypothesis whether correlation matrix is an identity matrix indicating whether the variables considered are unrelated. Small values of less than 0.05 significance level point out that factor analysis may be useful and appropriate for the considered data set. As shown in table 2, the p-value of the data was found to be Significant and KMO measure was 0.701 implying adequacy for application of exploratory factor analysis technique.

Table 2. Bartlett's test of sphericity and KMO test results

\begin{tabular}{lll}
\hline Kaiser-Meyer-Olkin (KMO) Measure of Sampling Adequacy & & 0.701 \\
\hline Bartlett's test of Sphericity & & 842.44 \\
& Df & 221 \\
& Sig. & 0.0 \\
\hline
\end{tabular}

Table 3 provides details about factors identified, corresponding factor loadings and Percentage of total variance explained by each of the factor. The findings were obtained by investigating the variables/factors/dimensions and the answers given by the respondents for the questions raised. Factor 1 (Broker's advice) consists of four variables explaining $18.68 \%$ of the Total variance and the core value of the factor corresponding to 3.134. Factor 2 (Personal Analysis) consists of three variables explaining 10.97\% of the Total variance and the core value of the factor corresponding to 1.94. Factor 3 (Online Trading Facilities) consists of three variables explaining 7.31\% of the Total variance and the core value of the factor corresponding to 1.29. Factor 4 (Current Market Price) consists of two variables explaining $6.64 \%$ of the Total variance and the core value of the factor corresponding to 1.25. Factor 5 (Analyst's Recommendation) consists of two variables explaining $5.86 \%$ of the Total variance and the core value of the factor corresponding to 0.97 .

Table 3. Exploratory factor analysis results

\begin{tabular}{lll}
\hline Factors & Factor Loads & $\begin{array}{l}\text { Percentage of Total Variance } \\
\text { Explained }\end{array}$ \\
\hline Factor 1: Broker's Advice & 3.134 & $18.68 \%$ \\
Factor 2: Personal Analysis & 1.94 & $10.97 \%$ \\
Factor 3: Online Trading Facilities & 1.29 & $7.31 \%$ \\
Factor 4: Current Market Price & 1.25 & $6.64 \%$ \\
Factor 5: Analyst's Recommendation & 0.97 & $5.86 \%$ \\
Announced total variance & & 48.46 \\
KMO measure of sampling adequacy & & 0.668 \\
Bartlett's test of sphericity (Chi-square value) & & 543.145 \\
Degree of freedom & & 132 \\
Significance & & 0.000 \\
\hline
\end{tabular}

KMO: Kaiser Meyer Olkin.

The factors identified and the results of the study provides insights to firms offering financial services in developing nation like India to keep these factors in mind while offering products/services or in their marketing campaigns while targeting retail investors of Indian equity market. Table 4 gives details about various Segments in the National Stock Exchange of India namely: Wholesale Debt Market Segment, Capital market segment, Equity Futures and Options segment, Currency Futures and Options Segment and Interest rate futures segment.

Table 4. Different market segments in national stock exchange (NSE), India (in Rs.Crores)

\begin{tabular}{llllll}
\hline Market Segment of NSE India & $\mathbf{2 0 1 0 - 1 1}$ & $\mathbf{2 0 1 1 - 1 2}$ & $\mathbf{2 0 1 2 - 1 3}$ & $\mathbf{2 0 1 3 - 1 4}$ & $\mathbf{2 0 1 4 - 1 5}$ \\
Capital Market Segment & $3,577,410$ & $2,810,893$ & $2,708,279$ & $2,808,488$ & $4,329,655$ \\
Equity Futures \& Options Segment & $29,248,221$ & $31,349,732$ & $31,533,004$ & $38,211,408$ & $55,606,453$ \\
Wholesale Debt Market Segment & 559,447 & 633,179 & 792,214 & 851,434 & 772,369 \\
Currency Futures \& Options Segment & $3,449,788$ & $4,674,990$ & $5,274,465$ & $4,012,513$ & $3,023,908$ \\
Interest Rate Futures Segment & 62 & 3,959 & 0.22 & 30,173 & 421,558 \\
Total & $36,834,927$ & $39,472,753$ & $40,307,962$ & $45,914,017$ & $64,153,943$ \\
\hline
\end{tabular}

Source: NSE Fact book 2015. 
Table 5 provides specific details pertaining to Capital market segment and provides a snapshot of what is in-stored for marketers in terms of number of trading days in a month, total number of companies traded in NSE Capital market segment, total number of traders and their trading Quantity as well as trading value and offers a glimpse of total market capitalization. With such a vast opportunity available for financial service firms to tap retail investors in Indian equity market, firms can benefit tremendously if the factors identified which influence retail investor's trading behavior is incorporated while offering products/services and specifically highlighting in their marketing campaigns while targeting retail investors of Indian equity market.

Table 5. Month-wise growth of capital market segment of NSE India in 2014-2015

\begin{tabular}{|c|c|c|c|c|c|c|c|c|}
\hline $\begin{array}{l}\text { Year and } \\
\text { Month }\end{array}$ & $\begin{array}{l}\text { No. of } \\
\text { Trading } \\
\text { Days }\end{array}$ & $\begin{array}{l}\text { No of } \\
\text { Companies } \\
\text { Traded }\end{array}$ & $\begin{array}{lr}\text { No } & \text { of } \\
\text { Traders } & \text { (in } \\
\text { Lakhs) } & \\
\end{array}$ & $\begin{array}{l}\text { Traded } \\
\text { Quantity (in } \\
\text { Lakhs) }\end{array}$ & $\begin{array}{l}\text { Trading Value } \\
\text { (in Rs. Crores) }\end{array}$ & $\begin{array}{l}\text { Demat } \\
\text { Quantity } \\
\text { Lakhs) } \\
\end{array}$ & $\begin{array}{r}\text { Traded } \\
\text { (in }\end{array}$ & $\begin{array}{l}\text { Market } \\
\text { Capitalization } \\
\text { Rs. Crores) }\end{array}$ \\
\hline 14-Apr & 18 & 1,551 & 1,245 & 162,762 & 272,703 & 162,762 & & $7,346,737$ \\
\hline 14-May & 21 & 1,551 & 1,812 & 267,896 & 436,022 & 267,896 & & $8,251,346$ \\
\hline 14-Jun & 21 & 1,553 & 1,790 & 265,607 & 421,688 & 265,607 & & $8,854,702$ \\
\hline 14-Jul & 22 & 1,555 & 1,643 & 215,580 & 391,428 & 215,580 & & $8,831,139$ \\
\hline 14-Aug & 19 & 1,554 & 1,273 & 154,647 & 294,758 & 154,647 & & $9,060,960$ \\
\hline 14-Sep & 22 & 1,555 & 1,673 & 226,512 & 383,261 & 226,512 & & $9,172,838$ \\
\hline 14-Oct & 18 & 1,555 & 1,194 & 135,771 & 271,191 & 135,771 & & $9,490,520$ \\
\hline 14-Nov & 18 & 1,558 & 1,367 & 171,279 & 329,638 & 171,279 & & $9,739,570$ \\
\hline 14-Dec & 22 & 1,551 & 1,525 & 177,522 & 354,473 & 177,522 & & $9,600,459$ \\
\hline 15-Jan & 21 & 1,549 & 1,610 & 190,136 & 383,872 & 190,136 & & $10,100,218$ \\
\hline $15-F e b$ & 20 & 1,503 & 1,584 & 204,018 & 392,718 & 204,018 & & $10,212,614$ \\
\hline 15-Mar & 21 & 1,514 & 1,612 & 190,047 & 397,903 & 190,047 & & $9,930,122$ \\
\hline
\end{tabular}

Source: NSE Fact book 2015.

\section{Conclusion}

Capital markets world-wide have significantly facilitated in conversion of savings and disposable income of people into investments both in developed as well as developing nations. Indian capital market is in a trajectory of growth with lot of retail investors participating enthusiastically. With such a vast opportunity available for financial service firms to tap retail investors in Indian equity market, firms can benefit tremendously if the factors identified which influence retail investor's trading behavior is incorporated while offering products/services and specifically highlight them in their marketing campaigns while targeting retail investors of Indian equity market. Many studies in literature have focused on psychological biases of individual investors who are trading in equity market without actually identifying the factors which influence Individual retail investor's trading behavior. This is one of those few studies in literature focusing on retail individual investors from a developing nation like India.

In this study we identified the factors which influence and affect retail investor's trading behavior in Indian equity market by using primary data collected from retail investors belonging to different age group, professional backgrounds and demographics of India. The results of the study suggests that factors like broker's advice, personal analysis, current price of the equity stock, financial analyst's recommendations, inclination towards online trading; investor's confidence in advice given by his/her financial advisor plays a major role in influencing and affecting trading behavior of retail investors. The results of the study gives insights to firms offering financial services in developing nation like India to keep these factors in mind while offering products/services or in their marketing campaigns while targeting retail investors of Indian equity market.

\section{References}

Altunışık, R., Coşkun, R., Bayraktaroğlu, S., \& Yıldırım, E. (2005). Sosyal Bilimlerde Araştırma Yöntemleri Spss Uygulamalı. Genişletilmiş (4th Bask1, pp. 212-214). İstanbul: Sakarya Kitabevi Yayınları.

Aziz, A. (2011). Sosyal Bilimlerde Araştırma Yöntemleri ve Teknikleri (6th Baskı, pp. 39-98). Ankara: Nobel Yayın Dağıtım. http://aop.eogrenme.anadolu.edu.tr/eKitap/ARY201U.pdf

Baker. M., \& Wurgler, J. (2007). Investor Sentiment in the Stock Market. Working Paper 13189, NBER Working Paper Series, Cambridge. Retrieved from http://www.nber.org/papers/w13189.pdf 
Büyüköztürk, Ş. (2002). Faktör analizi: Temel kavramlar ve ölçek geliştirmede kullanimi, kuram ve uygulamada eğitim yönetimi dergisi. Ankara Üniversitesi Eğitim Bilimleri Fakültesi, Eğitim Bilimleri Bölümü, 32, 470-483.

De Long, J., Bradford, A. S., Lawrence, H. S., \& Robert, J. W. (1990). Noise trader risk in financial markets. Journal of Political Economy, 98(4), 703-738. http://dx.doi.org/10.1086/261703

Girish, G. P., \& Rastogi, N. (2013). Efficiency of S\&P CNX Nifty Index Option of the National Stock Exchange (NSE), India, using Box Spread Arbitrage Strategy. Gadjah Mada International Journal of Business, 15(3), 269-285.

Haugen, R. A. (1999). The inefficient stock market. What Pays off and Why, Pren.

İslamoğlu, H. (2011). Sosyal Bilimlerde Araştırma Yöntemleri (2nd Baskı). İstanbul: Beta Basım Yayım Dağıtım. Retrieved from http://aop.eogrenme.anadolu.edu.tr/eKitap/ARY201U.pdf

Islamoğlu, M., Apan, M., \& Ayvali, A. (2015). Determination of Factors Affecting Individual Investor Behaviours: A Study on Bankers. International Journal of Economics and Financial Issues, 5(2), 531-543. Retrieved from http://www.econjournals.com/index.php/ijefi/article/download/1063/pdf

Singhania, K., \& Girish, G. P. (2015). Impact of Macroeconomic Events on Shanghai Stock Exchange. Asian Journal of Empirical Research, 6(5), 64-76. Retrieved from http://www.aessweb.com/pdf-files/1-152-5\%286\%292015-AJER-64-76.pdf

Loong, L. H. (2000). Separation of Financial and Nonfinancial activities in Singapore. BIS Review, 1-8. Retrieved from http://www.bis.org/review/r000626b.pdf

McCall. (2002). Employee Fringe Benefits. BNA Pension \& Benefits Reporter, 29, 27-51.

Neumann, J. V. (1944). Morgenstern, Theory of Games and Economic Behavior. Princeton: Princeton UP.

Odean, T. (1998). Volume, Volatility, Price and Profit When All Traders are Above Average. Journal of Finance, 53(6), 1887-1934. http://dx.doi.org/10.1111/0022-1082.00078

Oliver, S. (2002). Naïve Universalism. Ethnicities, 2(2), 274-279.

Polat, Y. (2012). Faktör Analizi Yöntemlerinin Karşılaştırmalı Olarak İncelenmesi ve Hayvancılık Denemesine Uygulanışı. Yayınlanmamış Doktora Lisans Tezi, Çukurova Üniversitesi Fen Bilimleri Enstitüsü, Adana. 16.

Ramiah, V., Xu, X., \& Moosa, I. A. (2015). Neoclassical finance, behavioral finance and noise traders: A review and assessment of the literature. International Review of Financial Analysis, 41, 89-100.

Shleifer, A., \& Robert, V. (1997). The limits of arbitrage. Journal of Finance, 52, 35-55. Retrieved from http://scholar.harvard.edu/files/shleifer/files/limitsofarbitrage.pdf

Stiglitz, J. E., \& Weiss, A. (1981). Credit Rationing in Markets with Imperfect Information. The American Economic Review, 71(3), 393-410. Retrieved from http://socsci2.ucsd.edu/ aronatas/project/academic/Stiglitz\%20credit.pdf

\section{Copyrights}

Copyright for this article is retained by the author(s), with first publication rights granted to the journal.

This is an open-access article distributed under the terms and conditions of the Creative Commons Attribution license (http://creativecommons.org/licenses/by/3.0/). 